\title{
Cholestasis Caused by Fasciola gigantica
}

\section{Fasciola Gigantica’ ya Bağlı Kolestaz}

\section{Remzi Beştaş ${ }^{1}$, Kendal Yalçin', Muttalip Çiç̧ek²}

'Department of Gastroenterology, Dicle University Faculty of Medicine, Diyarbakır, Turkey

${ }^{2}$ Department of Medical Microbiology, Dicle University Faculty of Medicine, Diyarbakır, Turkey

\begin{abstract}
Fascioliasis is an infectious disease caused by the hepatic trematodes Fasciola hepatica and Fasciola gigantica. Here, we report the case of Fasciola gigantica presenting with biliary obstruction and abdominal pain that was diagnosed and treated by endoscopic retrograde cholangiography (ERCP). A 46-year-old woman presented with right upper quadrant abdominal pain and jaundice. Physical examination revealed icterus and hepatomegaly. Laboratory findings revealed an increase in liver transaminases and bilirubin. Abdominal ultrasonography showed extrahepatic and intrahepatic bile duct dilatation. The patient underwent ERCP. One live Fasciola gigantica was removed from the common bile duct by ERCP. In conclusion, fascioliasis should be considered in the differential diagnosis of obstructive jaundice, especially in endemic regions, and it should be kept in mind that ERCP plays an important role in the diagnosis and treatment of these patients. To our knowledge, this is the second case report of Fasciola gigantica treated by ERCP in Turkey. (Turkiye Parazitol Derg 2014; 38: 201-4)
\end{abstract}

Key Words: Fasciola gigantica, biliary obstruction, ERCP

Received: 19.02.2014

Accepted: 31.03 .2014

\section{ÖZET}

Fasiyoliyazis karaciğer tremadotları olan Fasciola hepatica ve Fasciola gigantica tarafından meydana getirilen bir enfeksiyondur. Burada biliyer obstrüksiyon ve karın ağrısı ile başvuran ve endoskopik retrograd kolanjio pankreotografi (ERCP) ile tanı ve tedavisi yapılan Fasciola gigantica olgusu sunuldu. 46 yaşında bayan hasta sağ üst kadranda lokalize karın ağrısı ve sarılık şikayetleri ile yatııılı. Fizik muayenesinde skleralarda ikter ve hepatomegali olan hastanın laboratuar bulguları arasında karaciğer taransaminazları ve bilirubinde artış mevcuttu. Batın ultrasonografisinde koledokta ve intrahepatik safra yollarında dilatasyon olan hastaya ERCP yapıldı. ERCP ile koledoktan bir adet canlı Fasciola gigantica alındı. Sonuç olarak fasiyoliyazis obstrüktif sarılığın ayırıcı tanısında, özellikle de endemik bölgelerde düşünülmeli ve bu hastaların tanı ve tedavisinde ERCP'nin önemli bir yer tuttuğu bilinmelidir. Bu vaka bilgilerimize göre ülkemizde ERCP ile tedavi edilen ikinci fasciola gigantica vakası olma özelliğini taşımaktadır. (Turkiye Parazitol Derg 2014; 38: 201-4)

Anahtar Sözcükler: Fasciola gigantica, biliyer darlık, ERCP

Geliş Tarihi: 19.02.2014

Kabul Tarihi: 31.03.2014

Address for Correspondence / Yazışma Adresi: Dr. Remzi Beştaş, Department of Gastroenterology, Dicle University Faculty of Medicine, Diyarbakır, Turkey. Phone: +90 4122488001 E-mail: bestasr@gmail.com DOI:10.5152/tpd.2014.3212

CCopyright 2014 Turkish Society for Parasitology - Available online at www.tparazitolderg.org

CTelif hakkı 2014 Türkiye Parazitoloji Derneği - Makale metnine www.tparazitolderg.org web sayfasından ulaşılabilir. 


\section{INTRODUCTION}

Fascioliasis is an infection caused by flukes of the class Trematoda, most often characterized by fever, eosinophilia, and abdominal pain, although as many as one-half of patients may be asymptomatic. Humans are incidental hosts for Fasciola hepatica, commonly known as the sheep liver fluke, and Fasciola gigantica; these flukes cause similar illnesses in patients who become infected by ingesting contaminated watercress or water. The illness occurs worldwide, particularly in regions with intensive sheep or cattle production. The incidence of human infection has apparently increased over the past 20 years (1). Fascioliasis has two distinct clinical phases: one corresponding to the hepatic migratory phase of the life cycle of the flukes and the other corresponding to the presence of the parasites in their final location in the bile ducts (2).

Here, we report a case of Fasciola gigantica infection that was diagnosed endoscopically and treated by endoscopic extraction along with antiparasitic medication.

\section{CASE REPORT}

A 42-year old female patient was admitted to our clinics with jaundice, localized pain in the upper right quadrant of the abdomen, and loss of appetite. She was living in a village from which city with sheep and goats. She had a history of dill and parsley ingestion. Physical examination revealed jaundice and hepatomegaly. Laboratory investigations showed increases in liver transaminases, alkaline phosphatase (ALP), and total bilirubin levels. Eosinophil percent was within normal limits in the complete blood count. Abdominal ultrasonography revealed hepatomegaly and dilatation of extrahepatic and intrahepatic bile ducts. The patient underwent endoscopic retrograde cholangiopancreatography $(E R C P)$ for identification of cholestasis etiology. ERCP showed dilatation of extrahepatic and intrahepatic bile ducts and a filling defect in the common bile duct (Figure 1). After endoscopic sphincterotomy, one live fluke was removed during balloon extraction of the choledochus (Figure 2). The fluke was removed from the intestinal lumen by a basket (Figure 3). The liver flatworm was identified as Fasciola gigantica based on morphology. Single-dose triclabendazole was given to the patient. During the follow-up period, the symptoms and laboratory findings of the patient improved.

\section{DISCUSSION}

Fasciola gigantica is a parasitic flatworm of the class Trematoda, which causes tropical fascioliasis. It is regarded as one of the most important single platyhelminth infections of ruminants in Asia and Africa (3). In humans, the infection begins with the ingestion of watercress or contaminated water containing encysted larvae. The larva excysts in the stomach, penetrates the duodenal wall, escapes into the peritoneal cavity, and then passes through the liver capsule to enter the biliary tree. Human fascioliasis has two phases. The hepatic phase of the disease begins 1 to 3 months after ingestion of metacercariae, with penetration and migration through the liver parenchyma toward the biliary ducts (4-6). The hepatic phase is characterized by fever with chills, upper abdominal pain, hepatomegaly, mild hepatitis, weight loss, and prominent eosinophilia. Reports suggest that the clini-

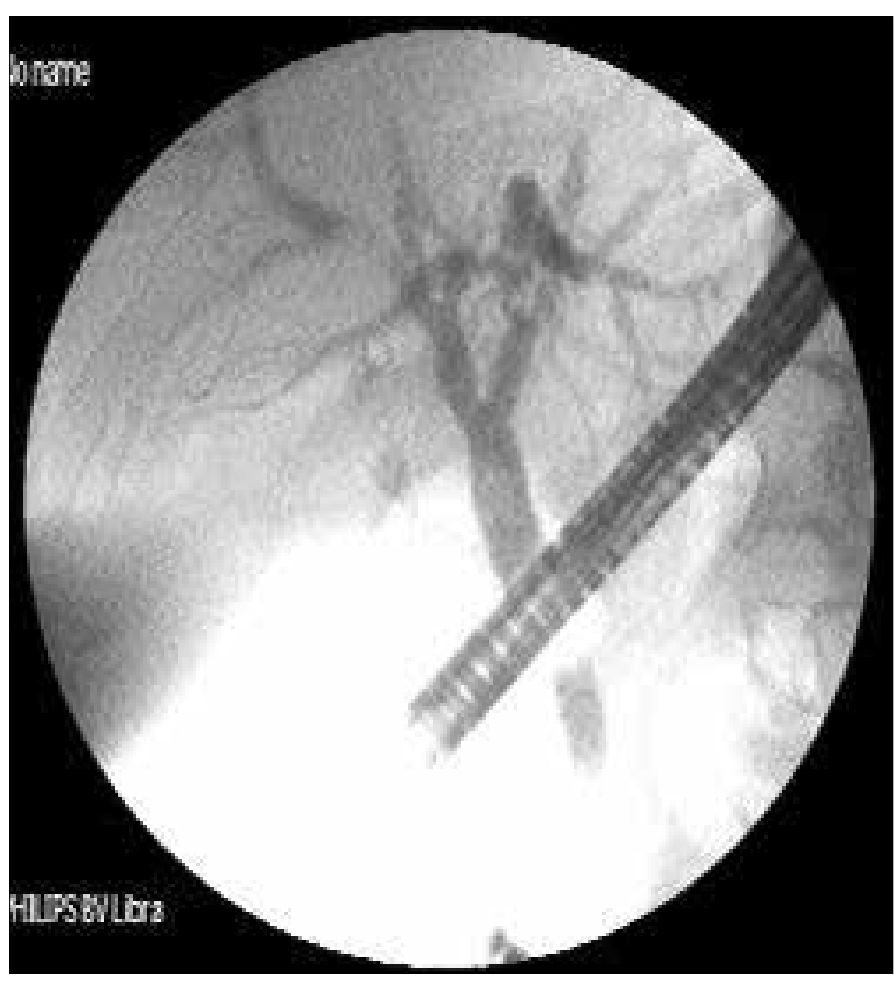

Figure 1. Filling defect in choledochus

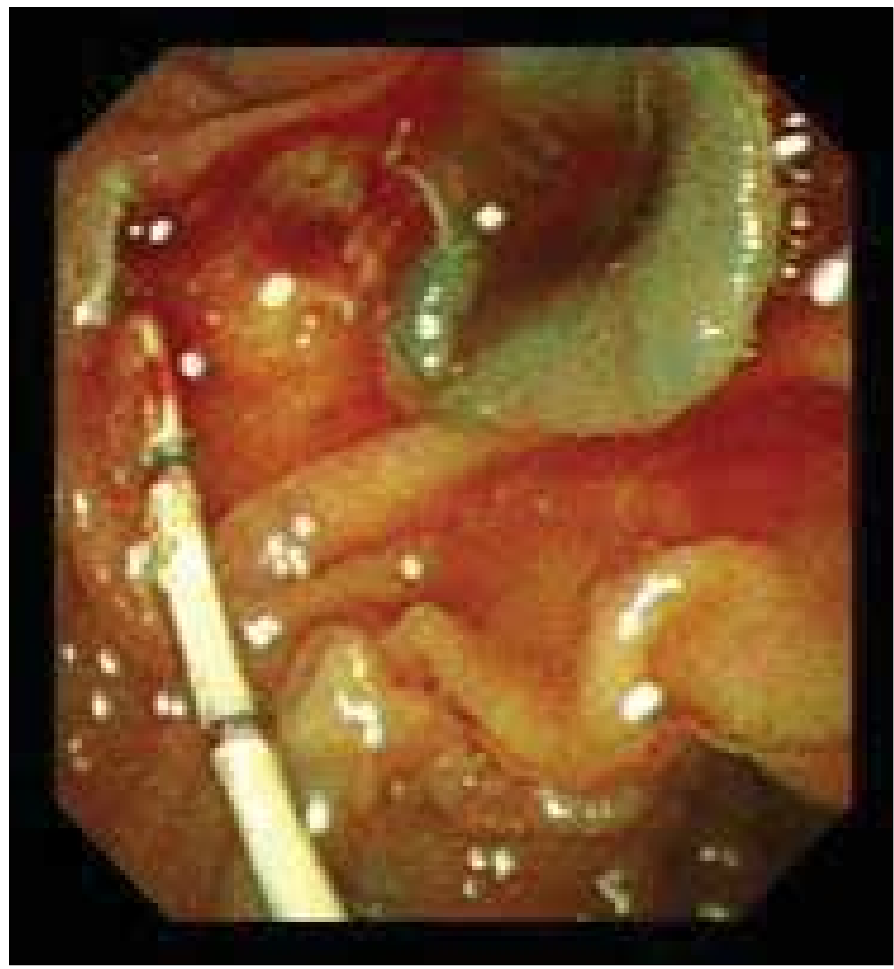

Figure 2. Alive fasciola gigantica

cal presentation of hepatic phase fascioliasis is similar to that of liver abscesses of other etiologies (7-10). In the biliary phase of the disease, patients often present with biliary colic, epigastric pain, jaundice, and abdominal tenderness due to the obstruction of the bile ducts by adult worms and the resultant inflammatory response. In this stage, the main laboratory findings are cholesta- 


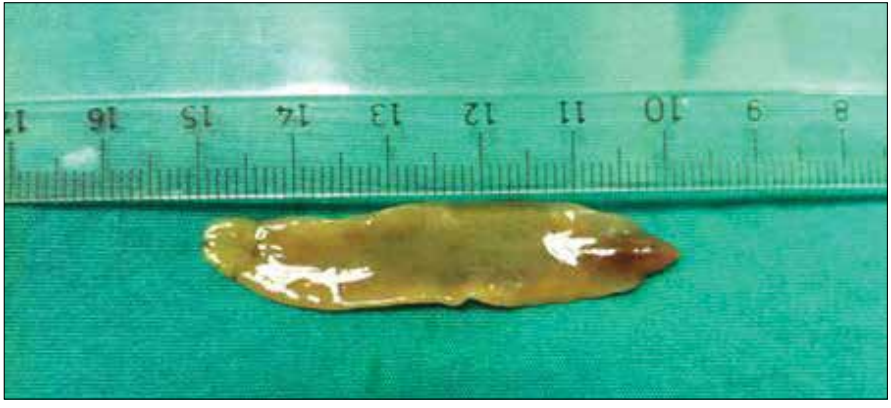

Figure 3. Fasciola hepatica in vitro

sis, including predominantly elevated serum ALP, gamma-glutamyl transferase (GGT), and total bilirubin (11-13).

The specific differentiation of trematodiases in general can be made by either a morphological study of adult flukes or by molecular tools. In the case of liver fluke infections, cholangiograms are useful, and biliary fascioliasis is characterized by non-specific biliary dilatation and single or multiple small filling defects, which represent flukes themselves. However, the conclusive diagnosis of biliary fascioliasis can be made by direct identification of flukes obtained from endoscopic or surgical removal or detection of typical eggs in bile from the duodenal tube (14).

In our region, no previous epidemiologic study reported the incidence of fascioliasis, but we previously conducted a single-center prospective study and found that fascioliasis is not rare in our region. These patients may often present with biliary obstruction and hepatitis (15).

Morphologic features of the flatworm in our case verified Fasciola gigantica. Eosinophilia was absent in the peripheral blood, and abdominal ultrasonography showed hepatomegaly. In addition, cholangiography revealed main bile duct dilatation and a filling defect. These features were in accordance with the biliary phase of the disease.

\section{CONCLUSION}

Fascioliasis is considered a rare cause of biliary obstruction. ERCP can be used for the diagnosis and treatment in patients who are admitted with fascioliasis and biliary obstruction. Furthermore, triclabendazole is an effective agent for medical therapy. We prescribed triclabendazole therapy after removal of Fasciola gigantica from the choledochus by ERCP. ERCP plays an important role in endemic regions of fascioliasis with biliary obstruction. This is the second case of Fasciola gigantica presenting with biliary obstruction that was diagnosed and treated with ERCP.

Ethics Committee Approval: Ethics committee approval was received for this study from the ethics committee of Dicle University.

Informed Consent: Written informed consent was obtained from patients who participated in this study.

Peer-review: Externally peer-reviewed.
Author Contributions: Concept - R.B., K.Y.; Design - R.B., K.Y.; Supervision - R.B., K.Y.; Funding - R.B., K.Y., M.Ç.; Materials R.B., K.Y., M.Ç.; Data Collection and/or Processing - R.B.; Analysis and/or Interpretation - R.B., K.Y., M.Ç.; Literature Review - R.B., K.Y.; Writer - R.B., K.Y.; Critical Review - R.B., K.Y.; Other R.B.

Conflict of Interest: No conflict of interest was declared by the authors.

Financial Disclosure: The authors declared that this study has received no financial support.

Etik Komite Onayı: Bu çalışma için etik komite onayı Dicle Üniversitesi'nden alınmıştır.

Hasta Onamı: Yazılı hasta onamı bu çalışmaya katılan hastalardan alınmıştır.

Hakem değerlendirmesi: Dış bağımsız.

Yazar Katkıları: Fikir - R.B., K.Y.; Tasarım - R.B., K.Y.; Denetleme - R.B., K.Y.; Kaynaklar - R.B., K.Y., M.Ç.; Malzemeler - R.B., K.Y., M.Ç.; Veri toplanması ve/veya işlemesi - R.B.; Analiz ve/veya yorum - R.B., K.Y., M.Ç.; Literatür taraması - R.B., K.Y.; Yazıyı yazan - R.B., K.Y.; Eleştirel İnceleme - R.B., K.Y.; Diğer - R.B.

Çıkar Çatışması: Yazarlar çıkar çatışması bildirmemişlerdir.

Finansal Destek: Yazarlar bu çalışma için finansal destek almadıklarını beyan etmişlerdir.

\section{REFERENCES}

1. Tolan RW Jr. Fascioliasis due to Fasciola hepatica and Fasciola gigantica infection: an update on this 'neglected' neglected tropical disease. Lab Med 2011; 42: 107-17. [CrossRef]

2. Marsden PD. Parasitic disease of the liver. Diseases of the Liver Philadelphia: Lippincott William and Wilkins Shiff 1999; 1078-88.

3. Dias LM, Silva R, Viana HL, Palhinhas M, Viana RL. Biliary fascioliasis: diagnosis, treatment and follow-up by ERCP. Gastrointest Endosc 1996; 43: 616-20. [CrossRef]

4. Lim JH, Mairiang E, Ahn GH. Biliary parasitic diseases including clonorchiasis, opisthorchiasis and fascioliasis. Abdom Imaging 2008; 33: 157-65. [CrossRef]

5. Koç Z, Ulusan S, Tokmak N. Hepatobiliary fascioliasis: imaging characteristics with a new finding. Diagn Interv Radiol 2009; 15: 247-51.

6. Kabaalioğlu A, Cubuk M, Senol U, Cevikol C, Karaali K, Apaydin A, et al. Fascioliasis: US, CT, and MRI findings with new observations. Abdom Imaging 2000; 25: 400-4. [CrossRef]

7. Van Beers B, Pringot J, Geubel A, Trigaux JP, Bigaignon G, Dooms G. Hepatobiliary fascioliasis: noninvasive imaging findings. Radiology 1990; 174: 809-10. [CrossRef]

8. Teichmann D, Grobusch MP, Göbels K, Müller HP, Koehler W, Suttorp N. Acute fascioliasis with multiple liver abscesses. Scand J Infect Dis 2000; 32: 558-60. [CrossRef]

9. Aksoy DY, Kerimoğlu U, Oto A, Ergüven S, Arslan S, Unal S, et al. Fasciola hepatica infection: clinical and computerized tomographic findings of ten patients. Turk J Gastroenterol 2006; 17: 40-5.

10. Kim KA, Lim HK, Kim SH, Lee WJ, Lim JH. Necrotic granuloma of the liver by human fascioliasis: imaging findings. Abdom Imaging 1999; 24: 462-4. [CrossRef]

11. Bektaş M, Dökmeci A, Cinar K, Halici I, Oztas E, Karayalcin S, et al. Endoscopic management of biliary parasitic diseases. Dig Dis Sci 2010; 55: 1472-8. [CrossRef] 
12. Ozer B, Serin E, Gümürdülü $Y$, Gür G, Yilmaz U, Boyacioğlu $S$. Endoscopic extraction of living Fasciola hepatica: case report and literature review. Turk J Gastroenterol 2003; 14: 74-7.

13. Gulsen MT, Savas MC, Koruk M, Kadayifci A, Demirci F. Fascioliasis: a report of five cases presenting with common bile duct obstruction. Neth J Med 2006; 64: 17-9.
14. Goral V, Senturk S, Mete O, Cicek M, Ebik B, Kaya B. A Case of biliary Fascioliasis by Fasciola gigantica in Turkey. Korean J Parasitol 2011; 49: 65-8. [CrossRef]

15. Kaya $M$, Beştaş $R$, Çetin $S$. Clinical presentation and management of Fasciola hepatica infection: single-center experience World J Gastroenterol 2011; 28: 4899-904. [CrossRef] 